\title{
Impact of Urbanization and Land-Use Change on Surface Climate in Middle and Lower Reaches of the Yangtze River, 1988-2008
}

\author{
Xiaowei Yao,, ${ }^{1,2}$ Zhanqi Wang, $^{1}$ and Hua Wang ${ }^{2}$ \\ ${ }^{1}$ School of Public Administration, China University of Geosciences, Wuhan 430074, China \\ ${ }^{2}$ Faculty of Earth Resources, China University of Geosciences, Wuhan 430074, China \\ Correspondence should be addressed to Zhanqi Wang; zhqwang@cug.edu.cn
}

Received 17 September 2014; Revised 12 January 2015; Accepted 20 January 2015

Academic Editor: R. B. Singh

Copyright (C) 2015 Xiaowei Yao et al. This is an open access article distributed under the Creative Commons Attribution License, which permits unrestricted use, distribution, and reproduction in any medium, provided the original work is properly cited.

Land-use/land cover change (LUCC) is one of the fundamental causes of global environmental change. In recent years, understanding the regional climate impact of LUCC has become a hot-discussed topic worldwide. Some studies have explored LUCC impact on regional climate in specific cities, provinces, or farming areas. However, the quick-urbanized areas, which are highly influenced by human activities, have the most severe land-use changes in developing countries, and their climatic impact cannot be ignored. This study aims to identify the impact of land-use change coupled with urbanization on regional temperature and precipitation in the metropolitan areas of middle and lower reaches of the Yangtze River in China by means of spatial analysis and numeric methods. Based on the exploration of land-use change and climate change during 1988-2008, the impact of landuse transition from non-built-up area to built-up area on temperature and precipitation was analyzed. The results indicated that the land-use conversion has affected the regional temperature with an increasing effect in the study area, while the influence on precipitation was not so significant. The results can provide useful information for spatial planning policies in consideration of regional climate change.

\section{Introduction}

It is widely recognized that land-use/cover change (LUCC) at local, regional, and global scales is one of the crucial driving factors of global climate change $[1,2]$. According to the fourth assessment report of Intergovernmental Panel on Climate Change (IPCC) in 2007, human activities, such as urbanization and agriculture, accounted for $90 \%$ of global warming [3]. This has been of great concern because innumerable consequent changes were produced on the earth. Some important researches showed that human-induced LUCC was one of the key factors which influence the regional climate [4-8]. LUCC exerts influences on the local and regional climate systems via biogeochemical and biogeophysical feedback mechanisms $[9,10]$. The biogeochemical impact of land-use change on the climate is produced by changing atmospheric concentrations of greenhouse gases (GHGs). In this way of feedback mechanism, LUCC mainly changes the carbon and nutrient cycling in the terrestrial ecosystem and affects the GHGs and aerosol exchange between surface and atmosphere [11]. The GHGs from agricultural land-uses, for instance, are estimated to account for $10-20 \%$ of the total global anthropogenic emissions, which has raised a wide range of concern about LUCC impact on climate change [12]. Besides, landuse change also plays an important role in climatic system by means of biogeophyisical effects. The biogeophyisical feedback mechanism basically manifests the changes of physical features of the earth's surface such as roughness, surface albedo, soil moisture, and vegetation coverage and structure, which influence the radiation, heat, and moisture exchange process between the surface and the atmosphere [13]. These effects directly result in the changes of surface temperature, humidity, wind speed, and precipitation, accordingly bringing more complex climate at large scales $[14,15]$. As the direct indicators of biogeophyisical feedback mechanism, land surface temperature and precipitation are useful observational 
evidence, so that they are widely applied to measure the climate changes [16-19]. And the land-use change data also produces great effect in the climate change assessment.

As an important source of considerable human activities, urbanization causes changes of the land-use/cover over the urban areas [20]. Many experiments have been conducted to understand that there is close relationship between urbanization and climate change [21]. The research by Kalnay and Cai, for instance, suggested that half of the observed decrease in diurnal temperature range is due to urban and other landuse changes [6]. Zhang et al. [22] simulated the influence of urbanization on climate in the Yangtze River Delta by the application of weather research and forecasting (WRF) model and found out that the conversion of rural land (mostly irrigated cropland) to urban land cover results in significant changes to the near-surface temperature, humidity, wind speed, and precipitation. Observations by Liao et al. [23] revealed that, by utilizing WRF/Chem model and MODIS data, intensive building clusters in mega cities in the Yangtze River Delta form the urban canopy layers and modify the surface energy budgets and surface roughness, which change thermal and dynamic characteristics of the surface layer. Both simulative and numerical analysis suggest that urban growth-driven land-use change significantly influences the surface heat balance, exchange of water vapor, and momentum between the atmosphere and the surface layer and consequently results in the changes of regional weather, especially the rainfalls [24-27]. But arguments on the effects of urban development on large-scale warming climate still exist [28]. At local scales, a lot of researches have been implemented focusing on urban heat island (UHI), which is a widely concerned issue [29]. Case studies by observations and remote sensing images such as Miao et al. [30] and $\mathrm{Wu}$ et al. [31] on Chinese cities and Singh et al. [20] on Delhi of India showed that the UHI generally took place in various types of cities in different regions, and the cases of extreme rainfall weather got increased [32,33].

Although there have been considerable reports of current researches, there is still much unknown about the impact of regional land-use change and urbanization on climate change. As the surface physical, chemical, and biological characters vary greatly across regions, the climatic influences of urbanization and land-use change vary correspondingly [14]. Due to the lack of data and knowledge, it has been widely recognized that this issue is of great importance for further exploration and discussion [34].

Since the overall economic reforms in the mid-1980s, China has experienced unprecedented urbanization. Cities in China started to face increasing climate risks $[35,36]$. The middle and lower reaches of the Yangtze River are one of the most developed regions across the country. Tens of big and medium sized cities are located along or near the Yangtze River, which are interconnected to consist of a considerable "Yangtze River Economic Belt" in the eastern and central China. There have been studies on the impact of LUCC on regional climate [22, 23,37], in some specific cities like Wuhan [31] and specific provinces like Jiangxi [38]. However, some physical characteristics such as elevation, latitude, or landforms may be ignored when investigating a specific city or province. In this study, we selected the metropolitan areas along the middle and lower reaches of the Yangtze River as the study area. The research would be of great significance because, on one hand, it could provide regional comparison analysis of climate changes resulting from land-use changes; on the other, it could be a guide to alleviating the climatic risks in the rapid urbanization process.

\section{Data and Methodology}

2.1. Study Area. The metropolitan area in the middle and lower reaches of the Yangtze River is located in $110^{\circ} 15^{\prime} \sim$ $123^{\circ} 25^{\prime} \mathrm{E}, 26^{\circ} 03^{\prime} \sim 33^{\circ} 25^{\prime} \mathrm{N}$ with a total area of $4.82 \times 10^{5} \mathrm{~km}^{2}$. It stretches across seven provincial regions from west to east, covering the central and east of Hubei, the northeast of Hunan, the north of Jiangxi, the central and south of Anhui, the south of Jiangsu, the north of Zhejiang, and entire Shanghai. In this region, there are tens of big cities such as Yichang, Yueyang, Nanchang, Hefei, Nanjing, Suzhou, and Hangzhou, involving Wuhan metropolitan, Changsha metropolitan, Poyang Lake metropolitan, Yangtze-side metropolitan Region of Anhui, and Yangtze River Delta metropolitan (Figure 1).

Mainly located in the Yangtze Plain with part of South Yangtze hills at this latitude, this area belongs to subtropical monsoon climate and subtropical moist monsoon climate region. Owing to moderate rainfall and sunlight, and with abundant amount of water resources, it is a fertile region which is famous for rice cultivation and fishery. It is an important grain producing area in China that plays a key role in the national agricultural industry. In addition, with the obvious locational superiority and favorable industrial and commercial basis, it is also one of the most dynamic economic regions across the country. Demographically, the proportion of urban population to permanent population in the study area also increased at an unprecedented speed since it rose from $19.8 \%$ in 1990 to $38.9 \%$ in 2000 , and then to 49.3\% in 2008 in the seven provinces, according to the official statistical data launched by National Bureau of Statistics of China and the involved provinces. At the same time, the regional land-use has changed severely. According to the land-use data extracted from remote sensing images, the total area of cultivated land was $215913 \mathrm{~km}^{2}$ in the late 1980s, which decreased by $13292 \mathrm{~km}^{2}$ to $202621 \mathrm{~km}^{2}$ in the year of 2008 . In contrast, the amount of built-up area grew significantly from $19135 \mathrm{~km}^{2}$ to $30008 \mathrm{~km}^{2}$ during this period, which was almost $56.8 \%$ more than that in the year of 1988. Except for the water bodies increasing from $36654 \mathrm{~km}^{2}$ to $38528 \mathrm{~km}^{2}$ during 1988-2008, the areas of forestry, grassland, and unused area all slightly decreased. Consequently, it is of great significance to explore the changes of built-up area and their influence on regional climate.

2.2. Data and Methods. The data used in this paper was collected from the data center of Chinese Academy of Sciences (CAS). It mainly included land-use data and meteorological data of the study area.

Land-use data was extracted from the Chinese subset of the Global Land Cover Characteristics database. The dataset is on the basis of land-use maps at the scale of 1:100000, 


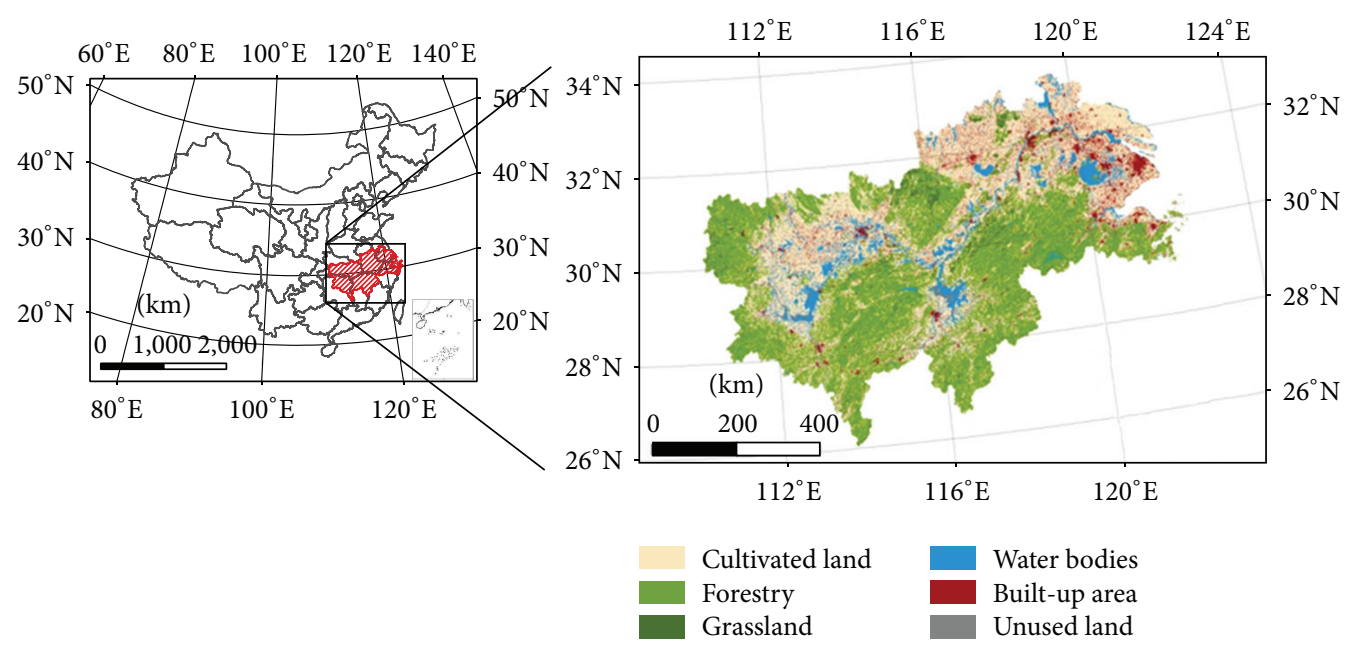

FIgURE 1: Location of the study area and the land cover, 2008.

using the classification system of 6 classes of first level and 25 classes of second level, which relied on interpretation of Landsat TM imagery and ground survey of 2000 with high level of accuracy (about $98.7 \%$ of the average degree of interpretation accuracy and $97.6 \%$ of comparing the changing patches of land-use between two periods) [39]. The land-use data involved in this study was originally generated with $1 \mathrm{~km}$ grid scale in the years of $1988,1995,2000,2005$, and 2008 with Albers projection, which is believed to be an effective kind of data that can provide sufficient information for the regional land-use change monitoring [40].

The meteorological data during 1988-2008 was collected from meteorological stations of China Meteorological Administration, including the annual near-surface temperature and annual average precipitation. Based on the observational data acquired from the 756 observation stations distributed across China's mainland (Figure 2), the 3year average data was calculated to represent the temperature/precipitation in the specific time points including 1988, 1995, 2000, 2005, and 2008. Then the observational data were interpolated into $1 \mathrm{~km}$ resolution grid data with Kriging Interpolation algorithm and were uniformly projected with Albers projection so that they could be spatially matched with land-use change data. During interpolation with temperature data, terrain conditions of the study area were taken into consideration. Therefore, the temperature data was first adjusted to the sea level. After interpolation, the digital elevation model (DEM) was applied to correct the data by $0.6^{\circ} \mathrm{C}$ per $100 \mathrm{~m}$ in height.

In order to explore the climatic impact of land-use change during the fast urbanization process, the land-use conversion matrix was first applied to calculate the total amount of conversion from non-built-up area to built-up area in each period of time. It is a fundamental tool in analysis of landuse change [41]. The conversion matrix was simplified here because only the changes from non-built-up area to built-up area were discussed in this paper (Table 1).

After the land-use conversions and the changes of temperature and precipitation during the study period were evaluated by gird on the ArcINFO platform, numerical analysis
TABLE 1: Land-use conversion matrix for non-built-up area to builtup area.

\begin{tabular}{|c|c|c|c|c|c|c|}
\hline & \multicolumn{5}{|c|}{$T 1$} \\
\hline & & $\mathrm{CU}$ & $\mathrm{FO}$ & GR & WA & UN \\
\hline$T 2$ & $\mathrm{BU}$ & $\begin{array}{l}S_{\mathrm{CU} 2 \mathrm{BU}} \\
P_{\mathrm{CU} 2 \mathrm{BU}}\end{array}$ & $\begin{array}{l}S_{\mathrm{FO} 2 \mathrm{BU}} \\
P_{\mathrm{FO} 2 \mathrm{BU}}\end{array}$ & $\begin{array}{l}S_{\mathrm{GR} 2 \mathrm{BU}} \\
P_{\mathrm{GR} 2 \mathrm{BU}}\end{array}$ & $\begin{array}{l}S_{\text {WA2BU }} \\
P_{\text {WA2BU }}\end{array}$ & $\begin{array}{l}S_{\mathrm{UN} 2 \mathrm{BU}} \\
P_{\mathrm{UN} 2 \mathrm{BU}}\end{array}$ \\
\hline
\end{tabular}

Note: CU, FO, GR, WA, UN, and BU refer to cultivated land, forestry, grassland, water bodies, unused land, and built-up area, respectively. $S$ and $P$ refer to the area and proportion of conversion from each land cover to builtup area, respectively, during $T 1$ to $T 2$. Hence, $S_{\mathrm{CU} 2 \mathrm{BU}}$ represents the amount of conversion from cultivated land to built-up area during the time $T 1$ to $T 2$, and $P_{\mathrm{CU} 2 \mathrm{BU}}$ refers to the conversion rate from cultivated land to built-up area during the time $T 1$ to $T 2$, and so on, which is calculated with the following equation: $P_{\mathrm{CU} 2 \mathrm{BU}}=\left(S_{\mathrm{CU} 2 \mathrm{BU}}-S_{\mathrm{CU}}\right) / S_{\mathrm{CU}} \times 100 \%$

was applied to examine their relationship. The parameter of $E$ could be used to describe the responses of climate changes to the land-use conversion. For each type of land-use conversion, consider the following:

$$
\begin{aligned}
& E_{t}=\frac{\sum_{1}^{m} \Delta I_{t}}{M}, \\
& E_{p}=\frac{\sum_{1}^{n} \Delta I_{p}}{N},
\end{aligned}
$$

where $E$ refers to the effects of land-use conversion to builtup area on temperature and precipitation, $t$ and $p$ refer to temperature and precipitation, respectively, $\Delta I$ represents the changes of the temperature/precipitation where conversion from non-built-up area to built-up area occurred, $m$ and $n$ mean the number of temperature/precipitation that changed, and $M$ and $N$ are the total amount of each land-use conversion type.

The research diagram for data handling and analysis is shown in Figure 3. 


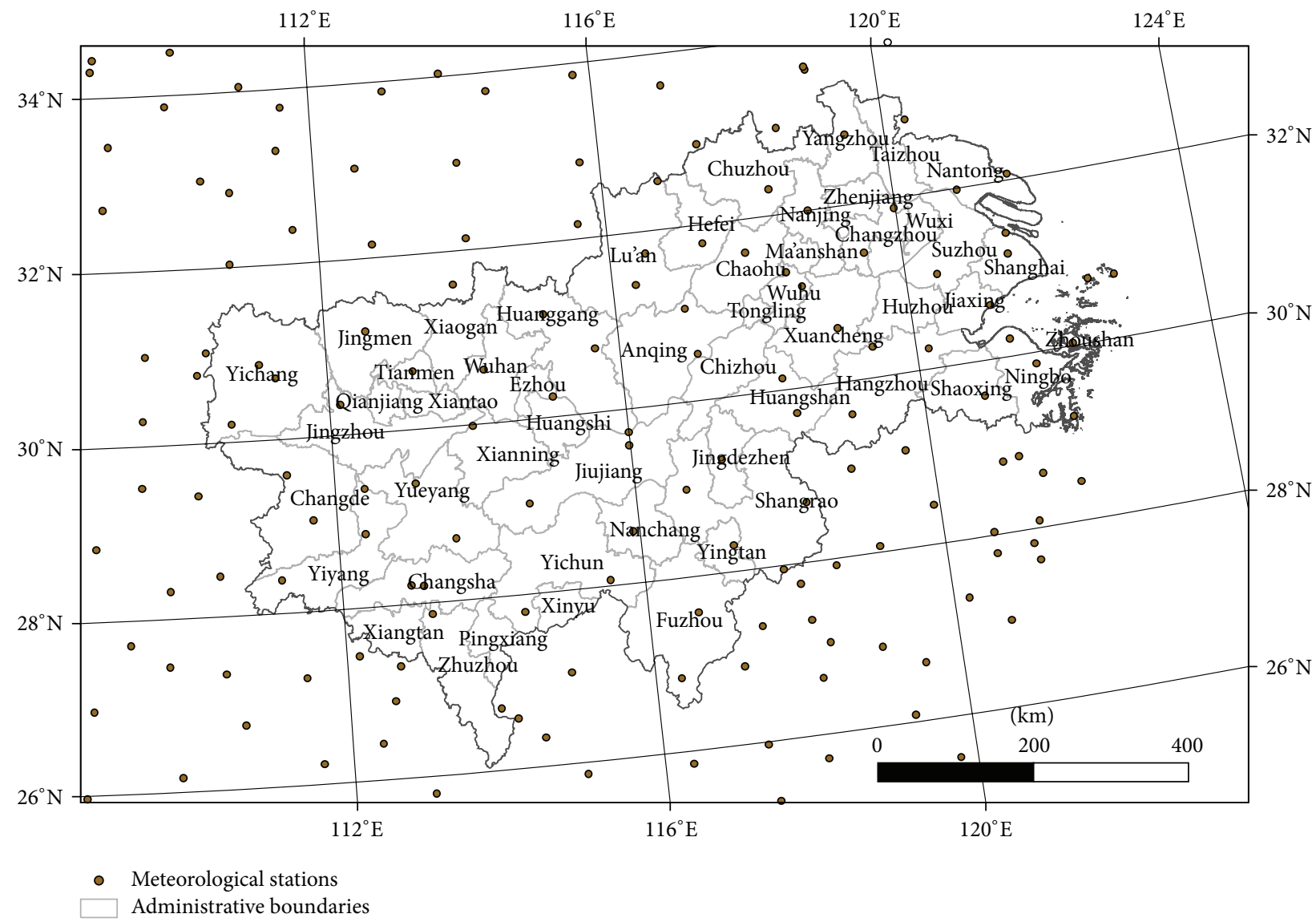

FIgURE 2: Distribution of the meteorological stations used for interpolation within and around the study area.

TABLE 2: Land-use conversion from non-built-up to built-up area, 1988-2008 (area unit: ten thousand hectares).

\begin{tabular}{|c|c|c|c|c|c|c|}
\hline \multicolumn{2}{|c|}{ Period/land-use conversion } & \multirow{2}{*}{$\frac{\text { CU2BU }}{147.62}$} & \multirow{2}{*}{$\frac{\text { FO2BU }}{16.12}$} & \multirow{2}{*}{$\frac{\text { GR2BU }}{1.65}$} & \multirow{2}{*}{$\frac{\text { WA2BU }}{12.08}$} & \multirow{2}{*}{$\begin{array}{c}\text { UN2BU } \\
0.30\end{array}$} \\
\hline 1988-1995 & Area & & & & & \\
\hline $1988-1990$ & Proportion & $6.84 \%$ & $0.84 \%$ & $1.02 \%$ & $3.30 \%$ & $1.47 \%$ \\
\hline \multirow{2}{*}{ 1995-2000 } & Area & 134.27 & 12.53 & 0.85 & 7.70 & 0.13 \\
\hline & Proportion & $6.33 \%$ & $0.65 \%$ & $0.52 \%$ & $2.12 \%$ & $0.66 \%$ \\
\hline \multirow{2}{*}{$2000-2005$} & Area & 161.13 & 18.62 & 1.81 & 11.40 & 0.18 \\
\hline & Proportion & $7.62 \%$ & $0.97 \%$ & $1.12 \%$ & $3.04 \%$ & $0.88 \%$ \\
\hline \multirow{2}{*}{$2005-2008$} & Area & 170.91 & 26.71 & 2.48 & 19.09 & 0.37 \\
\hline & Proportion & $8.28 \%$ & $1.39 \%$ & $1.54 \%$ & $4.93 \%$ & $2.11 \%$ \\
\hline
\end{tabular}

Note: the data was calculated according to land-use conversion matrix introduced in Table 1.

\section{Results and Discussion}

3.1. Spatiotemporal Changes of Built-Up Area Expansion during 1988-2008. According to the land cover data, the amount of built-up areas and the conversion from other land cover types could be calculated. The overall area of built-up areas in the metropolitans of the middle and lower reaches of the Yangtze River grew from $19135 \mathrm{~km}^{2}$ to $30008 \mathrm{~km}^{2}$. It can obviously be seen that the main conversion type to built-up area in the region was the conversion from cultivated land (Table 2).

Temporally, despite the areas of land cover conversion fluctuating in 1995-2005, the annual conversions of each type in the four periods were speeding significantly except for the conversion of grassland, water bodies, and unused land in 1995-2000. The years of 2005-2008 were the most prominent time that built-up area expanded while occupying other five land covers. During these three years, about $8.28 \%$ of the cultivated land and $4.93 \%$ of the water bodies were lost and the proportion of built-up area increased from 5.64\% in 2005 to $6.24 \%$ in 2008 . In the year of 1988 , however, the percentage of the built-up area was just 3.97\% (Figure 4).

Spatially, most of the built-up areas were distributed in a zigzag manner along with the Yangtze River, with Shanghai metropolitan as the center (Figure 5). Another part of the built-up areas was located in the south of the Yangtze River, 


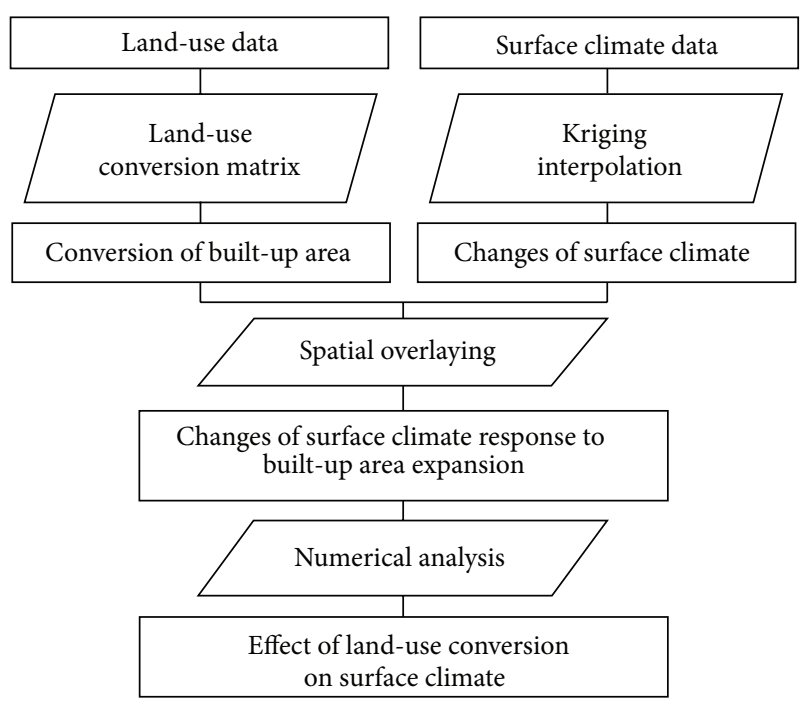

FIGURE 3: Research diagram for data handling and analysis.

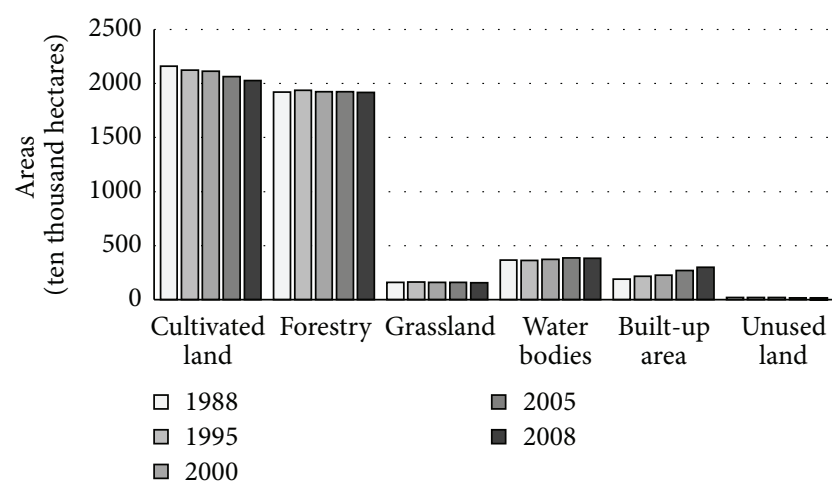

FIGURE 4: Structures of land-use in the middle and lower reaches of the Yangtze River, 1988-2008.

with Changsha and Nanchang as the centers. By dividing the study area into two parts including the middle reaches metropolitan region and the lower reaches metropolitan region, we could make out that approximately $64 \%$ of landuse conversions were found in the lower reaches metropolitan region, even though the area accounted for about $42 \%$ of the overall region. In the middle reaches metropolitan region, the average proportion of cultivated land conversion in the total conversion types was $72.8 \%$, followed by $16.8 \%$ of forestry conversion and about $9 \%$ of water bodies conversion, respectively, whose trends were on the rolling rise. In the lower reaches metropolitan region, the average proportion of cultivated land conversion in the total conversion types dominated in $88.3 \%$ with a descending trend since 2000 . The ratios of conversion from water bodies and forestry were both about $5 \%$ before 2005 , but with a slight increasing trend to over 7\% during 2005-2008.

3.2. Spatiotemporal Changes of the Regional Climates during 1988-2008. Generally, there were distinct changes in annual average temperature and precipitation in the metropolitans

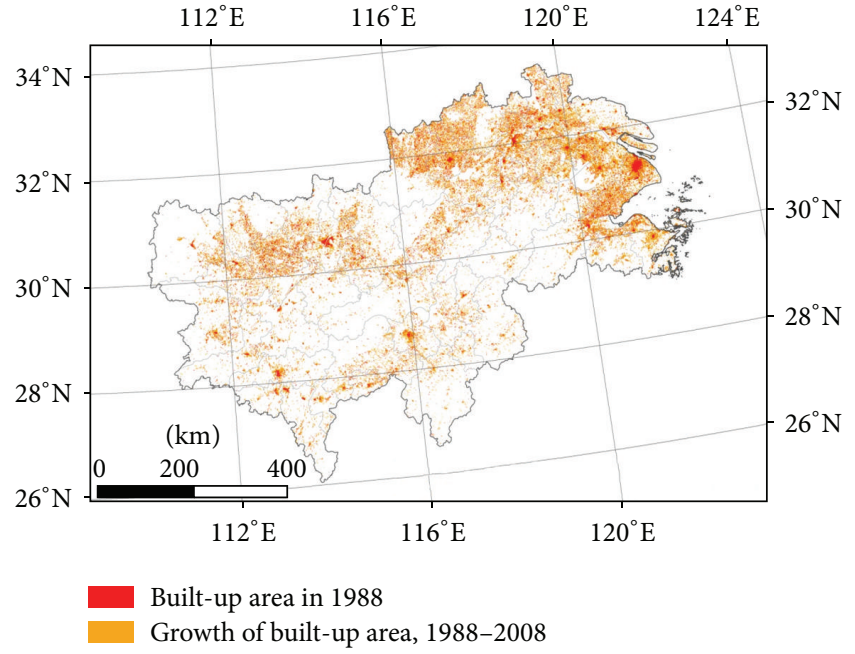

Figure 5: Distribution of built-up area, 1988-2008.

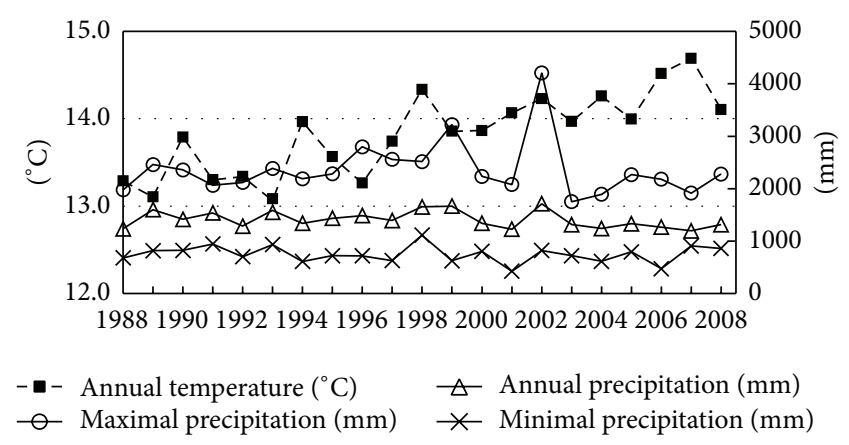

FIGURE 6: Temporal changes of temperature and precipitation in the study area, 1988-2008.

of middle and lower reaches of the Yangtze River from 1988 to 2008. The temperature showed an increasing trend in fluctuations in the study area, with the average temperature rising from $13.3^{\circ} \mathrm{C}$ in 1988 to $14.1^{\circ} \mathrm{C}$ in 2008 (Figure 6). Most of the regions had an increase of the annual temperature, except a tiny part of the hilly areas such as the north of Yichang and the south of Zhuzhou having a slight decrease of $0-$ $1.5^{\circ} \mathrm{C}$. The maximal rise of temperature that almost reached $6.7^{\circ} \mathrm{C}$ took place in the Hangzhou metropolitan, the west part of Yichang in Hubei Province, and the southeast corner of Shangrao in Jiangxi Province. Besides, the temperature basically increased $2.4-4.9^{\circ} \mathrm{C}$ in the majority of other parts of the region, including Shanghai, Nanjing, Wuhan, and Changsha metropolitans (Figure 7(a)).

At the same time, the annual precipitation in the study area did not show a significant rising or descending trend (Figure 6). The peak with $1713.7 \mathrm{~mm}$ appeared in the year of 2002 , and then the amount of rainfall fluctuated at a relatively lower level from 2003 to 2008. In addition, the changes of precipitation varied greatly across the area. On one side, the rainfalls showed a rising trend in the majority part of the region, with the maximum increase of $76.7 \mathrm{~mm}$ in the north-central part of Huangshan. On the other side, they 


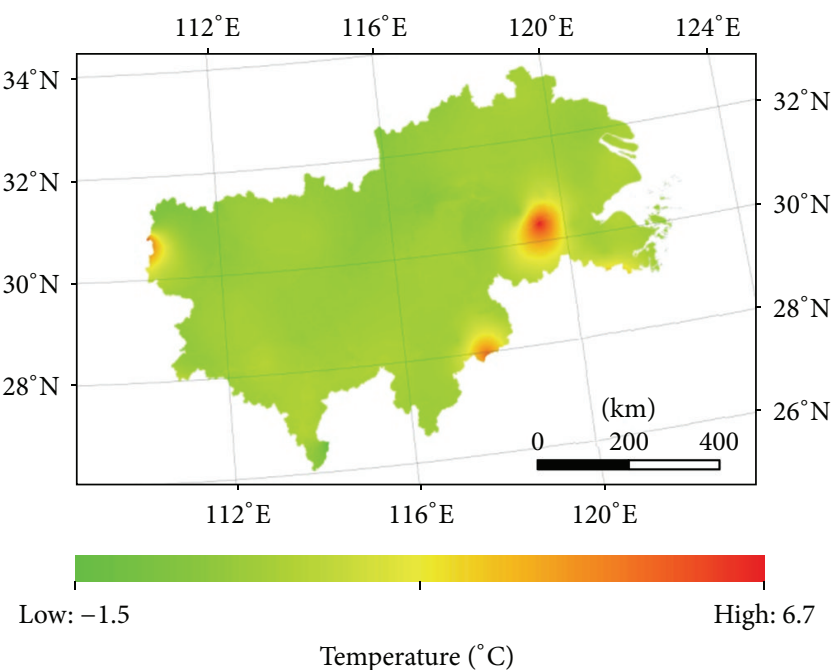

(a)

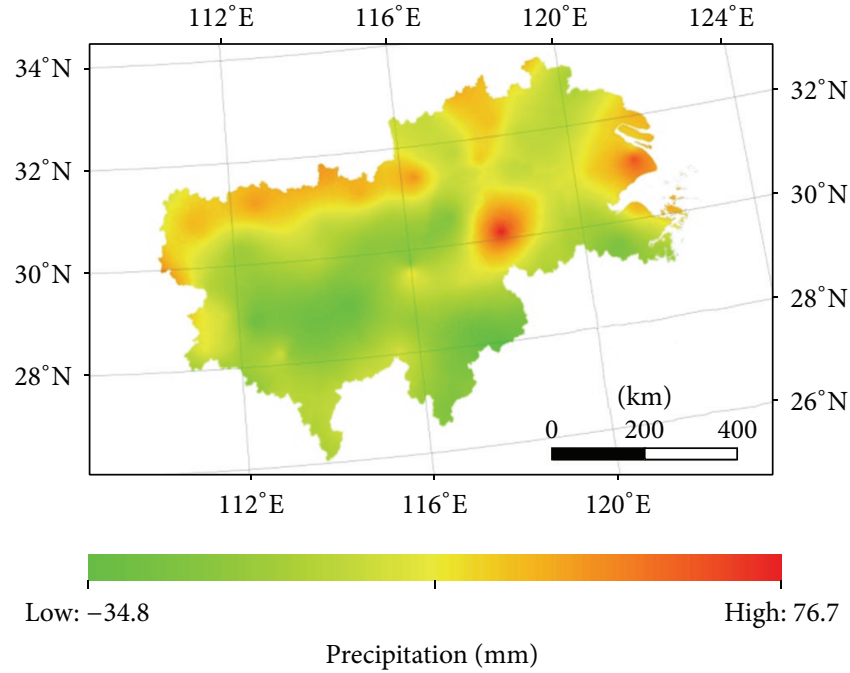

(b)

FiguRE 7: Changes in spatial distribution of annual average temperature (a) and precipitation (b) in the middle and lower reaches of the Yangtze River, 1988-2008.

showed a downward variation in the north part of Hunan, the southeast of Hubei, the southwest of Anhui, the east of Jiangxi, and east areas of Hangzhou, with the maximal decrease of $34.8 \mathrm{~mm}$. According to the results mentioned above, it can be concluded that the process of urbanization in this region has affected the regional climate to a certain extent (Figure 7(b)).

\subsection{Effects of Land-Use Conversion on Temperature and} Precipitation. We overlaid the built-up area growth maps with the climate change maps, and the variations of the climate responses to the land-use change showed significant differences in spatial distribution (Figure 8). Most of the metropolitan areas including the interior of Jianghan Plain, Wuhan, Changsha, Nanchang, Hefei, and the Yangtze River Delta Region got warmer in 1995 than in 1988 while a mass of cultivated land surrounding these cities and towns was lost due to urbanization. Part of the nearby water bodies, especially in Wuhan and so forth, was also turned to builtup area. When the trends of built-up area expansion and cultivated land loss kept going on for the next over 10 years, the changes of the temperature varied across the region. The urbanized areas with upward temperatures were not as concentrated as they were in the late 1980s; besides, fluctuations with downward temperatures occurred in some of the metropolitans such as Shanghai (Figures $8(\mathrm{a}), 8(\mathrm{~b})$, $8(\mathrm{c})$, and $8(\mathrm{~d})$ ).

The precipitation in spatial distribution significance across the region was not very obvious compared to the match of temperature with land-use change. The amounts of rainfall increased around Shanghai but decreased in Nanjing and Hefei metropolitans in 1988-1995. Another typical fluctuation was found in Nanchang metropolitan, the north of Jiangxi. The precipitation in this region went up in 1988-1995 and 2000-2005 but sharply cut down in 1995-2000 and 20052008 (Figures 8(e), 8(f), 8(g), and 8(h)).

The calculation results of $E$ showed the relativity of urbanizing land-use change with regional climate which matched the spatial layout analysis above (Figure 8). During the four time periods, the changes of regional average temperature were basically in accordance with the impact of other four types of conversion, especially with the grassland conversion and forestry conversion, except that of unused land turning to built-up areas, but the influence of the conversions got smaller (Figure 9(a)). These observations indicated that each type of conversion from non-built-up to built-up area had a positive influence on temperature changes. As we have known that when land-use cover such as natural vegetation and crops is replaced with the nonevaporating and nontranspiring built-up areas, surface properties such as albedo and soil moisture generally become lower. These changes may have an influence on heat and moisture exchange process between the surface and atmosphere and thus result in the rise of temperature.

According to the numeric observations, the land-use conversion from non-built-up to built-up areas did not have particular significance on precipitation changes in the study area during 1988-2008 (Figure 9(b)). There were both increase and decrease in precipitation when the built-up area expanded. The changing trends of rainfall almost reacted in the opposite directions between the four periods. Among the four types of land-use change, conversion from unused land to built-up area had the most severe impact on precipitation both in positive and in negative directions during the four periods, while conversion from cultivated land to built-up areas had the least influence on it. These differences in time sequence and land conversion types indicated that there is still uncertainty about the impact of LUCC on surface climate in this region, even though there is reduction in evapotranspiration due to urbanization [20]. 

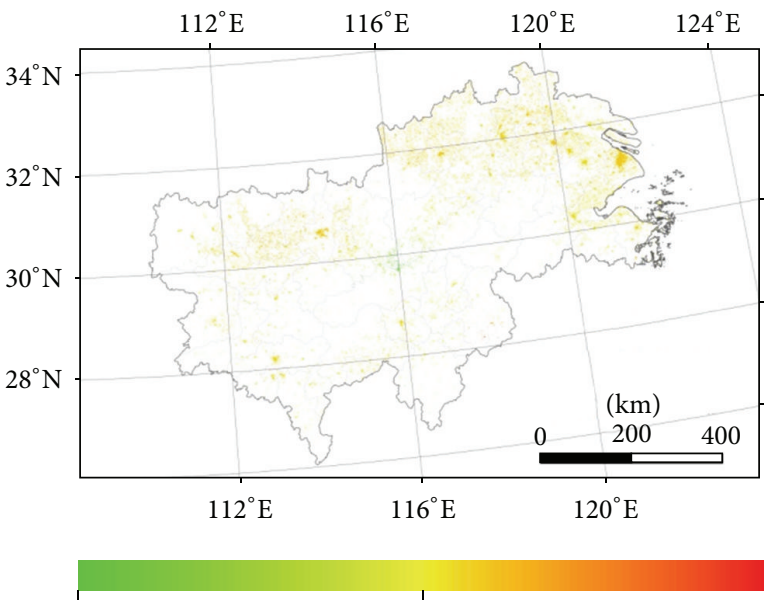

Low: -3.9

Temperature $\left({ }^{\circ} \mathrm{C}\right)$

(a)

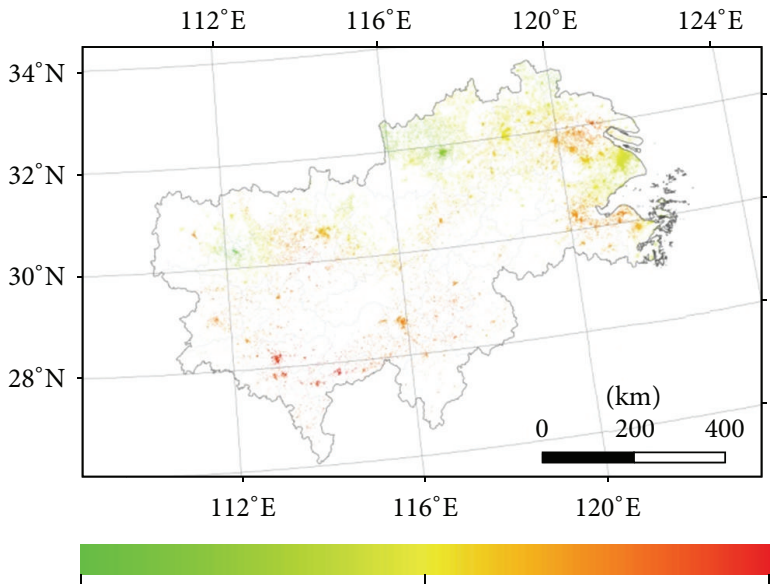

Low: -0.6

Temperature $\left({ }^{\circ} \mathrm{C}\right)$

(c)

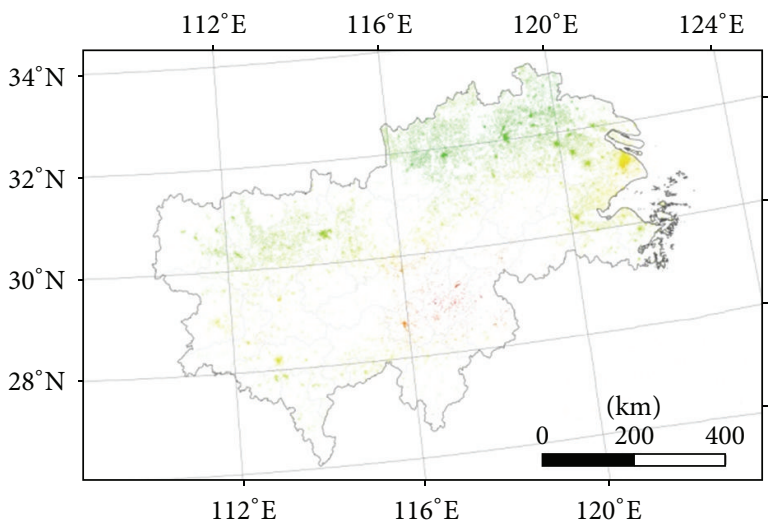

$116^{\circ} \mathrm{E}$

Low: -130.1

Precipitation (mm)

(e)
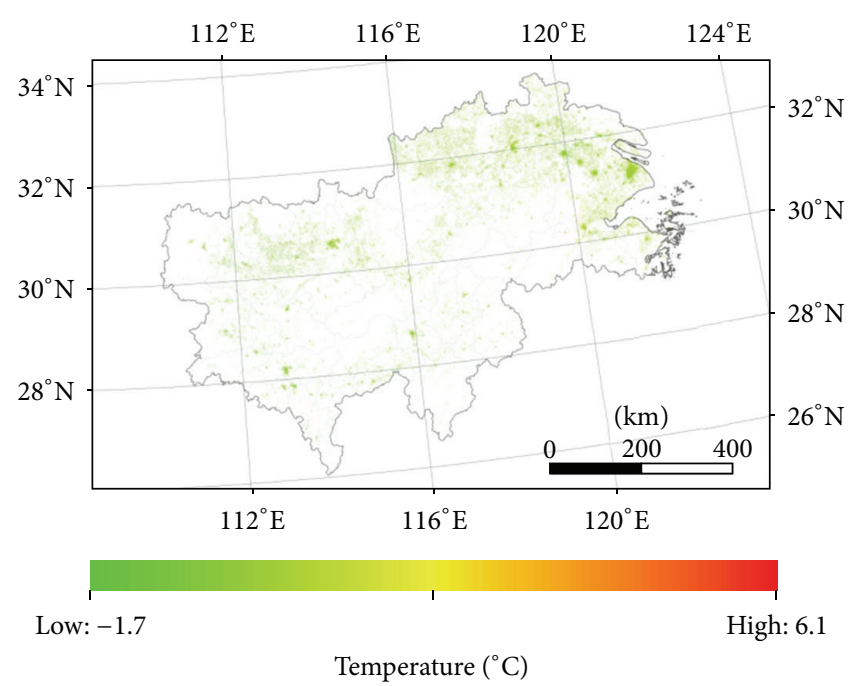

(b)

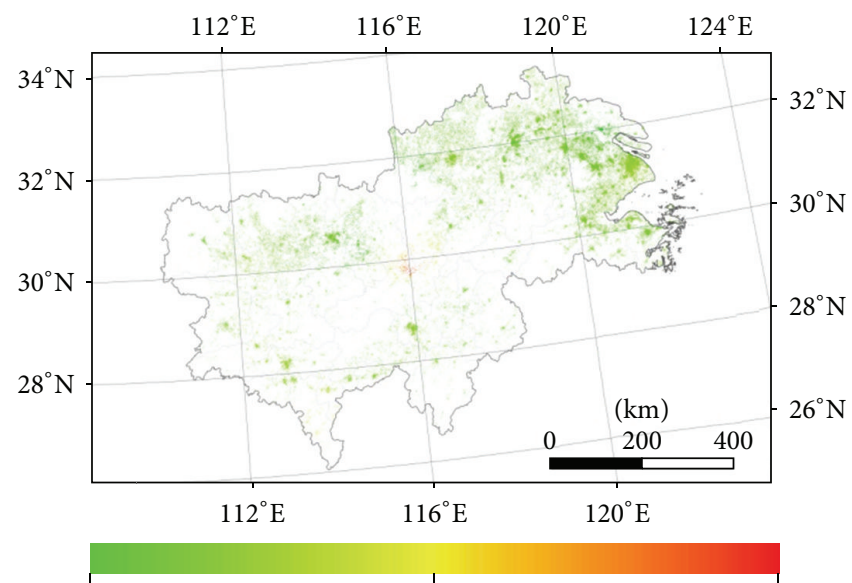

High: 4.0

Temperature $\left({ }^{\circ} \mathrm{C}\right)$

(d)

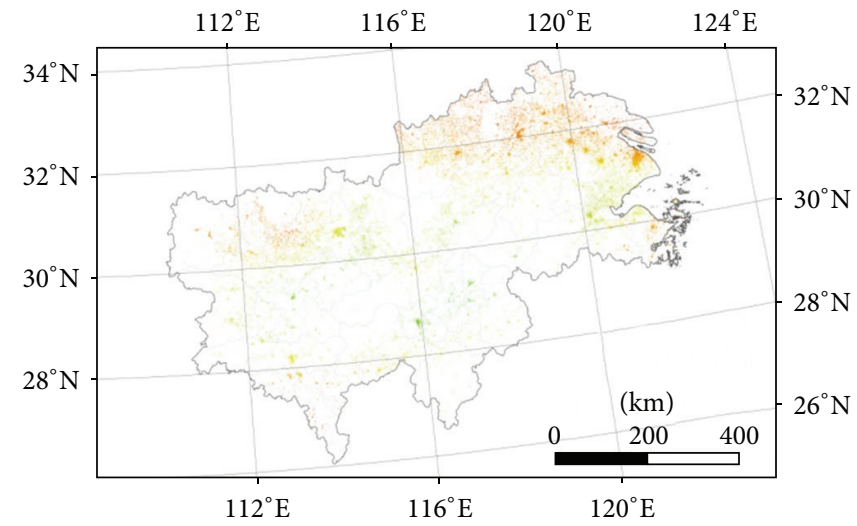

High: 707.1 Low: -718.9

High: 528.5

(f)

FIGURE 8: Continued. 

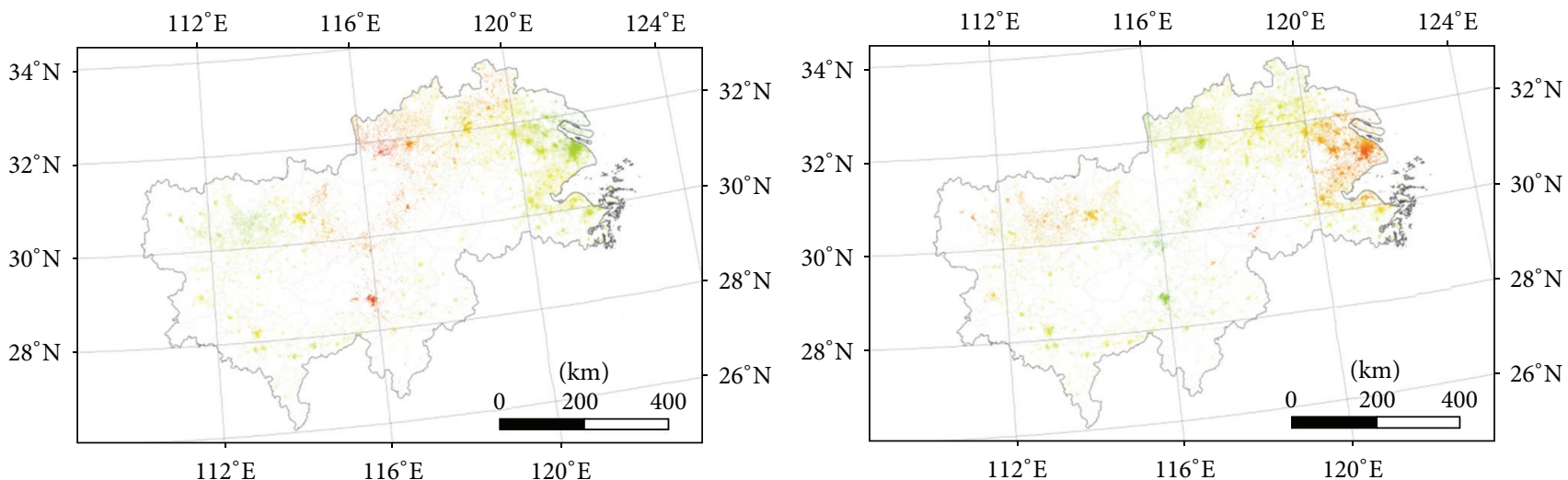

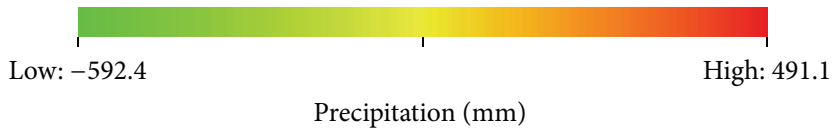

(g)

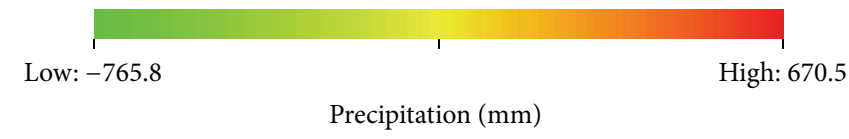

(h)

FIGURE 8: Variations of the temperature and precipitation response to land-use conversion from non-built-up to built-up area in periods 1988-1995 (a, e), 1995-2000 (b, f), 2000-2005 (c, g), and 2005-2008 (d, h).

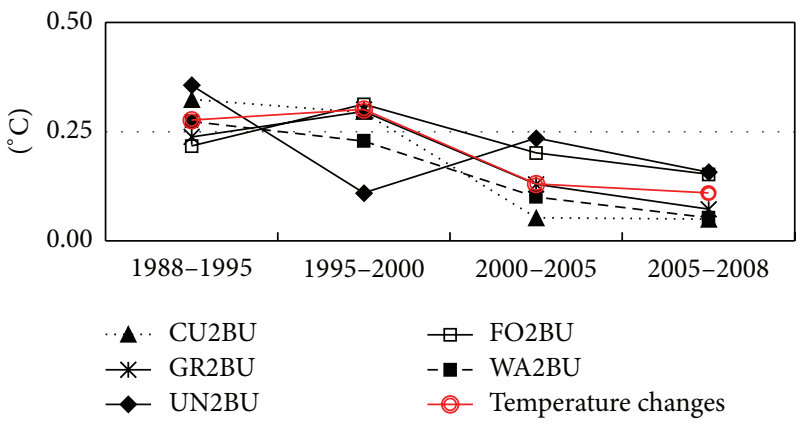

(a)

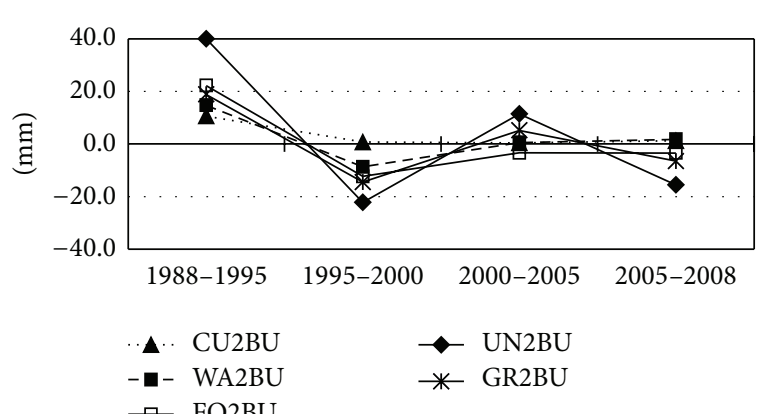

(b)

Figure 9: Changes of temperature (a) and precipitation (b) upon land-use conversions from non-built-up to built-up area.

\section{Conclusions}

In this paper, the impact of the land-use conversion from non-built-up areas to built-up areas on surface temperature and precipitation in the middle and lower reaches of the Yangtze River during 1988-2008 was examined by using spatial and numeric analysis. The results showed that conversion from cultivated land to built-up area was the most important type of land-use change in the region under the rapid urbanization process, which was recognized as "urbanization of land" and concentrated much of focuses from academia. The loss of water bodies was another important source that made the growth of built-ups.

The numeric results indicated that the transitions from non-built-up areas to built-up areas had positive relationship with the rising trend of regional temperature in the study area, but the effects of different conversion types in different periods were varied obviously. All the conversion types except the unused land transition have very similar impact on the changes of temperature. Within the 20-year time period, the upward and downward changing trend of regional temperature was quite in accordance with that where grassland and forestry were changed to built-up areas. These trends were increasing first and then went down significantly. The change of regional climate slightly went up from $0.28^{\circ} \mathrm{C}$ in $1988-1995$ to $0.3^{\circ} \mathrm{C}$ in $1995-2000$, but both the warming effects of conversion from cultivated land and from water bodies on temperature change decreased steadily in this period of time, which kept on going downwards significantly to the bottom of $0.05^{\circ} \mathrm{C}$ during 2005-2008. As to the regional precipitation, the results did not show much significant impact of land-use conversions from non-built-up areas to built-up areas, even though there were some researches that indicate it could result in either increasing or decreasing effect on precipitation $[27,42]$.

Generally, we have only focused on the physical climatic impact of transition from non-built-up to built-up areas in the urbanized area of the middle and lower reaches of the Yangtze River in this paper. The land-use change of transition from non-built-up to built-up areas influences the regional 
temperature mainly by altering the land surface net radiation and latent heat flux. The results are of great value for the state governments to guide land resource distribution and urbanization policies that respond to the regional climate changes.

Although the precipitation effect was also under consideration in this research, either the positive or negative influence was observed, probably due to the limited annual statistical data or the numeric methods involved. However, trapped by the limitations and the uncertainties of full understanding of the procedure mechanisms, the regional climate change is a very complicated process and there are many other factors that may take effect. As a consequence, it is a rather challenging goal to assess and quantize the climatic effects of land-use change since various biogeophysical and biogeochemical processes interact or even offset each other on the climate change [43]. Besides, the lack of forecasting climate changes in future under the land-use change was another inadequacy of the research. And the explorations would be more notable if the simulation was added by socioeconomic indicators such as population and industries.

\section{Conflict of Interests}

The authors declare that there is no conflict of interests regarding the publication of this paper.

\section{Acknowledgments}

This research was cosupported by National Natural Science Foundation of China (Grant no. 41101535), China Postdoctoral Science Foundation funded project (Grant no. 2012M521503), and Fundamental Research Funds for the Central Universities, China University of Geosciences (Wuhan) (Grant no. CUG120861). The authors also wanted to thank China National Natural Science Funds for Distinguished Young Scholar (Grant no. 71225005) for data support.

\section{References}

[1] J. A. Foley, R. Defries, G. P. Asner et al., "Global consequences of land use," Science, vol. 309, no. 5734, pp. 570-574, 2005.

[2] R. A. Pielke, "Land use and climate change," Science, vol. 310, no. 5754, pp. 1625-1626, 2005.

[3] R. Pachauri and A. Reisinger, IPCC Fourth Assessment Report, IPCC, Geneva, Switzerland, 2007.

[4] G. B. Bonan, "Effects of land use on the climate of the United States," Climatic Change, vol. 37, no. 3, pp. 449-486, 1997.

[5] C. M. Taylor, E. F. Lambin, N. Stephenne, R. J. Harding, and R. L. H. Essery, "The influence of land use change on climate in the Sahel," Journal of Climate, vol. 15, no. 24, pp. 3615-3629, 2002.

[6] E. Kalnay and M. Cai, "Impact of urbanization and land-use change on climate," Nature, vol. 423, no. 6939, pp. 528-531, 2003.

[7] M. Cai and E. Kalnay, "Climate: impact of land-use change on climate," Nature, vol. 427, no. 6971, p. 214, 2004.

[8] H. Paeth, K. Born, R. Girmes, R. Podzun, and D. Jacob, "Regional climate change in tropical and Northern Africa due to greenhouse forcing and land use changes," Journal of Climate, vol. 22, no. 1, pp. 114-132, 2009.
[9] L. Jiang, E. J. Ma, and X. Z. Deng, "Impacts of irrigation on the heat fluxes and near-surface temperature in an inland irrigation area of Northern China," Energies, vol. 7, no. 3, pp. 1300-1317, 2014.

[10] P. J. Lawrence, J. J. Feddema, G. B. Bonan et al., "Simulating the biogeochemical and biogeophysical impacts of transient land cover change and wood harvest in the community climate system model (CCSM4) from 1850 to 2100," Journal of Climate, vol. 25, no. 9, pp. 3071-3095, 2012.

[11] K. L. Findell, E. Shevliakova, P. C. D. Milly, and R. J. Stouffer, "Modeled impact of anthropogenic land cover change on climate," Journal of Climate, vol. 20, no. 14, pp. 3621-3634, 2007.

[12] P. H. Verburg, K. Neumann, and L. Nol, "Challenges in using land use and land cover data for global change studies," Global Change Biology, vol. 17, no. 2, pp. 974-989, 2011.

[13] P. J. Grutzen and M. O. Andreae, "Biomass burning in the tropics: impact on atmospheric chemistry and biogeochemical cycles," Science, vol. 250, no. 4988, pp. 1669-1678, 1990.

[14] X. Deng, C. Zhao, and H. Yan, "Systematic modeling of impacts of land use and land cover changes on regional climate: a review," Advances in Meteorology, vol. 2013, Article ID 317678, 11 pages, 2013.

[15] X. Deng, C. Zhao, Y. Lin et al., "Downscaling the impacts of large-scale LUCC on surface temperature along with IPCC RCPs: a global perspective," Energies, vol. 7, no. 4, pp. 2720-2739, 2014.

[16] F. Wang and Q. S. Ge, "Estimation of urbanization bias in observed surface temperature change in China from 1980 to 2009 using satellite land-use data," Chinese Science Bulletin, vol. 57, no. 14, pp. 1708-1715, 2012.

[17] H. Y. Ding and W. Z. Shi, "Land-use/land-cover change and its influence on surface temperature: a case study in Beijing City," International Journal of Remote Sensing, vol. 34, no. 15, pp. 55035517, 2013.

[18] W. Junkermann, J. Hacker, T. Lyons, and U. Nair, "Land use change suppresses precipitation," Atmospheric Chemistry and Physics, vol. 9, no. 17, pp. 6531-6539, 2009.

[19] A. T. Woldemichael, F. Hossain, and R. Pielke Sr., "Impacts of postdam land use/land cover changes on modification of extreme precipitation in contrasting hydroclimate and terrain features," Journal of Hydrometeorology, vol. 15, no. 2, pp. 777800, 2014.

[20] R. B. Singh, A. Grover, and J. Y. Zhan, "Inter-seasonal variations of surface temperature in the urbanized environment of Delhi using landsat thermal data," Energies, vol. 7, no. 3, pp. 1811-1828, 2014.

[21] R. B. Singh and C. Shi, "Advances in observation and estimation of land use impacts on climate changes: improved data, upgraded models, and case studies," Advances in Meteorology, vol. 2014, Article ID 748169, 14 pages, 2014.

[22] N. Zhang, Z. Q. Gao, X. M. Wang, and Y. Chen, "Modeling the impact of urbanization on the local and regional climate in Yangtze River Delta, China," Theoretical and Applied Climatology, vol. 102, no. 3-4, pp. 331-342, 2010.

[23] J. B. Liao, T. J. Wang, X. M. Wang et al., "Impacts of different urban canopy schemes in WRF/Chem on regional climate and air quality in Yangtze River Delta, China," Atmospheric Research, vol. 145-146, pp. 226-243, 2014.

[24] H. C. Wan, Z. Zhong, X. Q. Yang, and X. Q. Li, "Impact of city belt in Yangtze River Delta in China on a precipitation process in summer: a case study," Atmospheric Research, vol. 125-126, pp. 63-75, 2013. 
[25] A. Pathirana, H. B. Denekew, W. Veerbeek, C. Zevenbergen, and A. T. Banda, "Impact of urban growth-driven landuse change on microclimate and extreme precipitation-a sensitivity study," Atmospheric Research, vol. 138, pp. 59-72, 2014.

[26] R. A. Memon, D. Y. C. Leung, and C.-H. Liu, "An investigation of urban heat island intensity (UHII) as an indicator of urban heating," Atmospheric Research, vol. 94, no. 3, pp. 491-500, 2009.

[27] C.-Y. Lin, W.-C. Chen, S. C. Liu, Y. A. Liou, G. R. Liu, and T. H. Lin, "Numerical study of the impact of urbanization on the precipitation over Taiwan," Atmospheric Environment, vol. 42, no. 13, pp. 2934-2947, 2008.

[28] D. E. Parker, "A demonstration that large-scale warming is not urban," Journal of Climate, vol. 19, no. 12, pp. 2882-2895, 2006.

[29] A. J. Arnfield, "Two decades of urban climate research: a review of turbulence, exchanges of energy and water, and the urban heat island," International Journal of Climatology, vol. 23, no. 1, pp. 1-26, 2003.

[30] S. G. Miao, F. Chen, M. A. LeMone, M. Tewari, Q. C. Li, and Y. C. Wang, "An observational and modeling study of characteristics of urban heat island and boundary layer structures in Beijing," Journal of Applied Meteorology and Climatology, vol. 48, no. 3, pp. 484-501, 2009.

[31] H. Wu, L.-P. Ye, W.-Z. Shi, and K. C. Clarke, "Assessing the effects of land use spatial structure on urban heat islands using $\mathrm{HJ}-1 \mathrm{~B}$ remote sensing imagery in Wuhan, China," International Journal of Applied Earth Observation and Geoinformation, vol. 32, pp. 67-78, 2014.

[32] R. K. Kaufmann, K. C. Seto, A. Schneider, Z. Liu, L. Zhou, and W. Wang, "Climate response to rapid urban growth: evidence of a human-induced precipitation deficit," Journal of Climate, vol. 20, no. 10, pp. 2299-2306, 2007.

[33] Y.-Z. Cao, S. Wang, G. Zhang, J. Luo, and S. Lu, "Chemical characteristics of wet precipitation at an urban site of Guangzhou, South China," Atmospheric Research, vol. 94, no. 3, pp. 462-469, 2009.

[34] J. J. Feddema, K. W. Oleson, G. B. Bonan et al., "The importance of land-cover change in simulating future climates," Science, vol. 310, no. 5754, pp. 1674-1678, 2005.

[35] X. Deng, J. Huang, S. Rozelle, and E. Uchida, "Growth, population and industrialization, and urban land expansion of China," Journal of Urban Economics, vol. 63, no. 1, pp. 96-115, 2008.

[36] X. Deng and X. Bai, "Sustainable urbanization in Western China," Environment, vol. 56, no. 3, pp. 12-24, 2014.

[37] C. Gu, L. Hu, X. Zhang, X. Wang, and J. Guo, "Climate change and urbanization in the Yangtze River Delta," Habitat International, vol. 35, no. 4, pp. 544-552, 2011.

[38] Q. Wang, D. Riemann, S. Vogt, and R. Glaser, "Impacts of land cover changes on climate trends in Jiangxi province China," International Journal of Biometeorology, vol. 58, no. 5, pp. 645660, 2014

[39] M. Li, J. Wu, and X. Deng, "Identifying drivers of land use change in China: a spatial multinomial logit model analysis," Land Economics, vol. 89, no. 4, pp. 632-654, 2013.

[40] Z. H. Li, X. Z. Deng, J. K. Huang, and R. R. Zhang, “Critical studies on integrating land-use induced effects on climate regulation services into impact assessment for human wellbeing," Advances in Meteorology, vol. 2013, Article ID 831250, 14 pages, 2013.

[41] T. Takada, A. Miyamoto, and S. F. Hasegawa, "Derivation of a yearly transition probability matrix for land-use dynamics and its applications," Landscape Ecology, vol. 25, no. 4, pp. 561-572, 2010.
[42] Y. Lin, A. Liu, E. Ma, X. Li, and Q. Shi, "Impacts of future urban expansion on regional climate in the Northeast megalopolis, USA," Advances in Meteorology, vol. 2013, Article ID 362925, 10 pages, 2013.

[43] R. A. Pielke Sr., G. Marland, R. A. Betts et al., "The influence of land-use change and landscape dynamics on the climate system: Relevance to climate-change policy beyond the radiative effect of greenhouse gases," Philosophical Transactions of the Royal Society A: Mathematical, Physical and Engineering Sciences, vol. 360, no. 1797, pp. 1705-1719, 2002. 

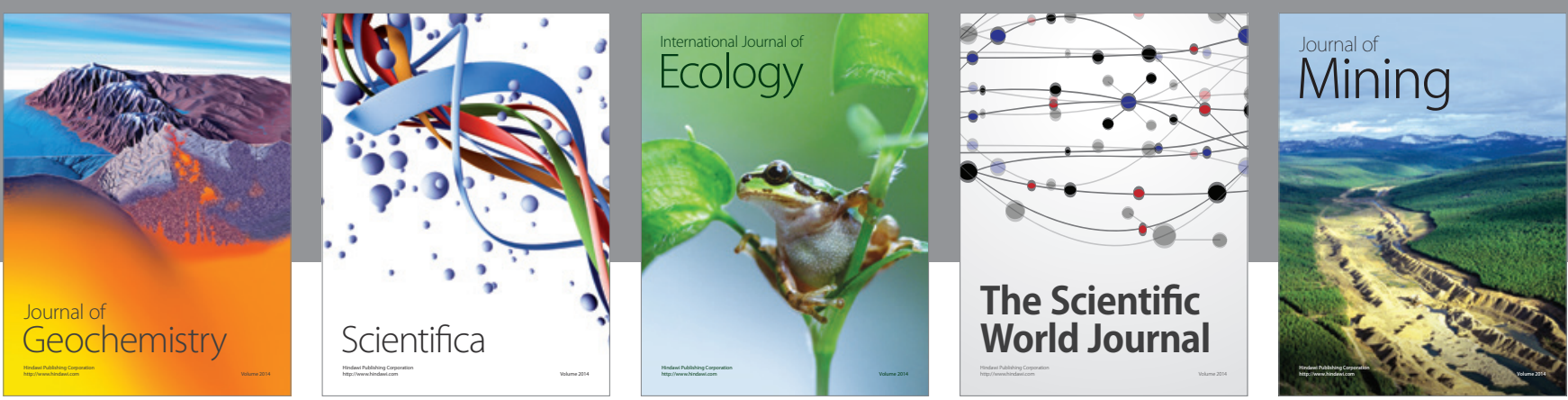

The Scientific World Journal
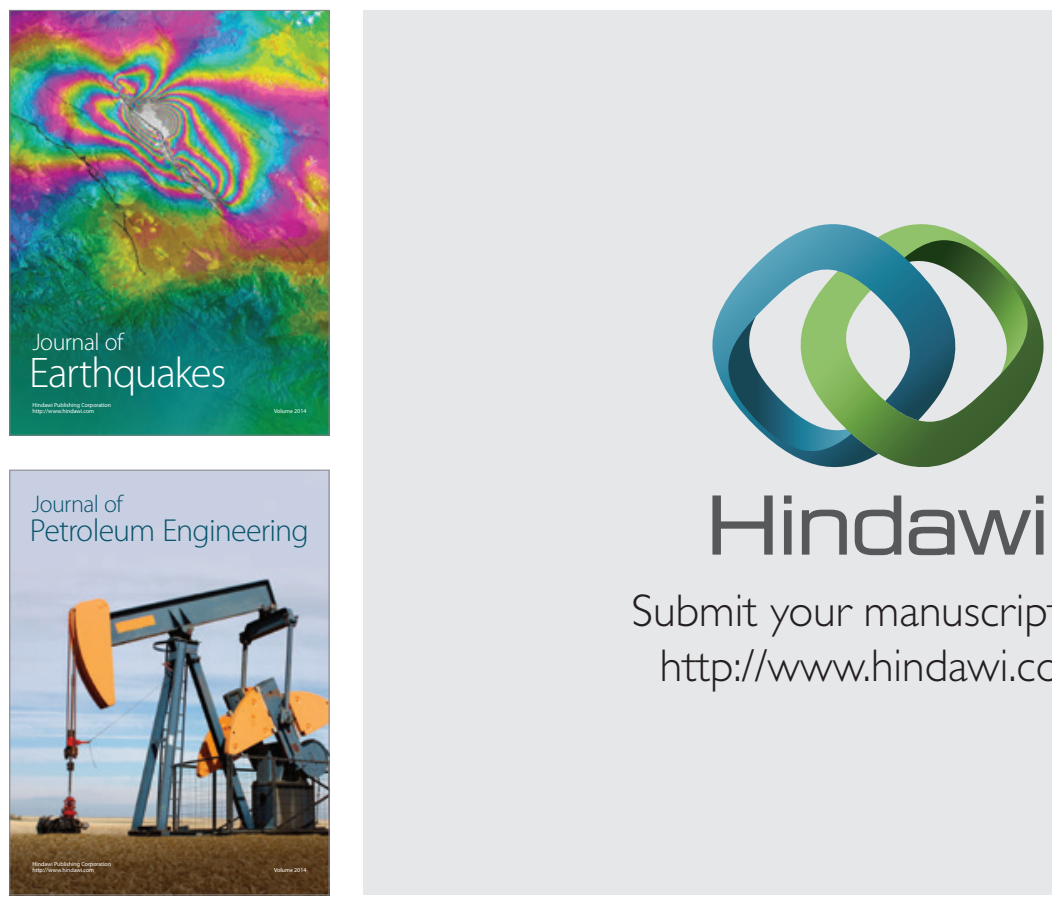

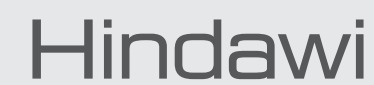

Submit your manuscripts at

http://www.hindawi.com
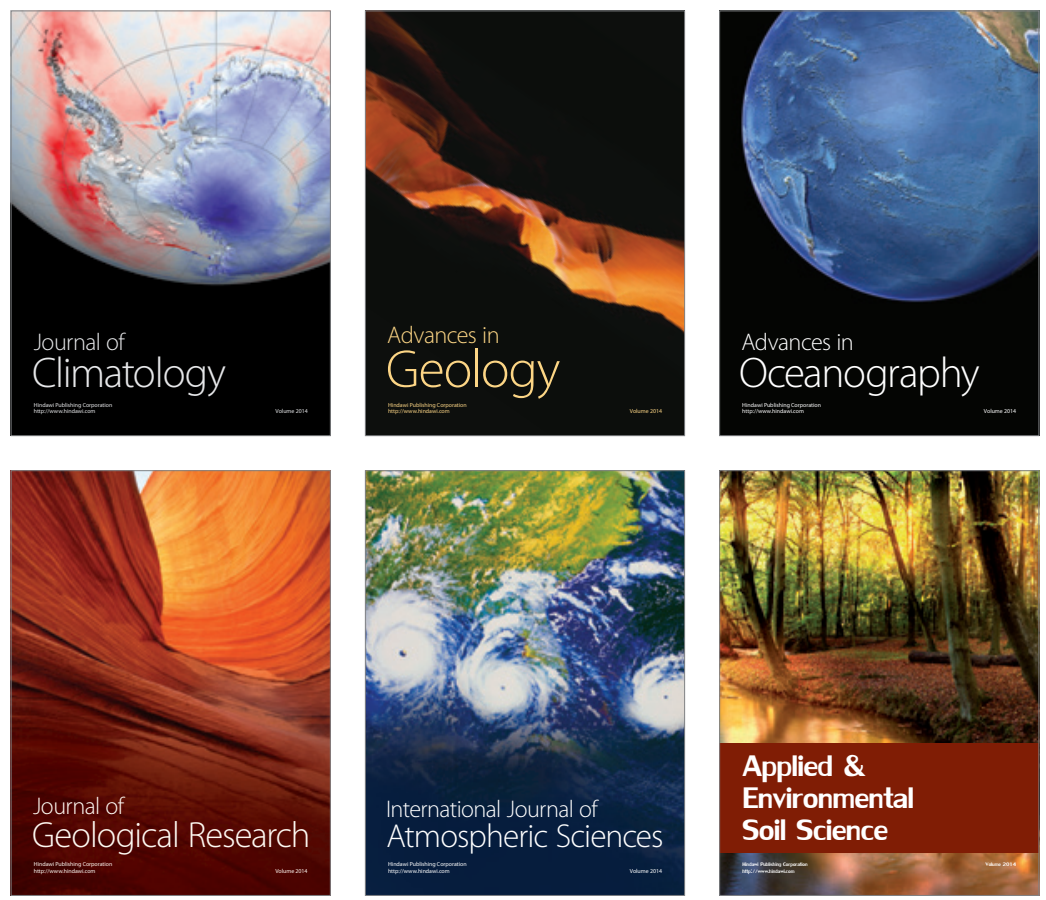
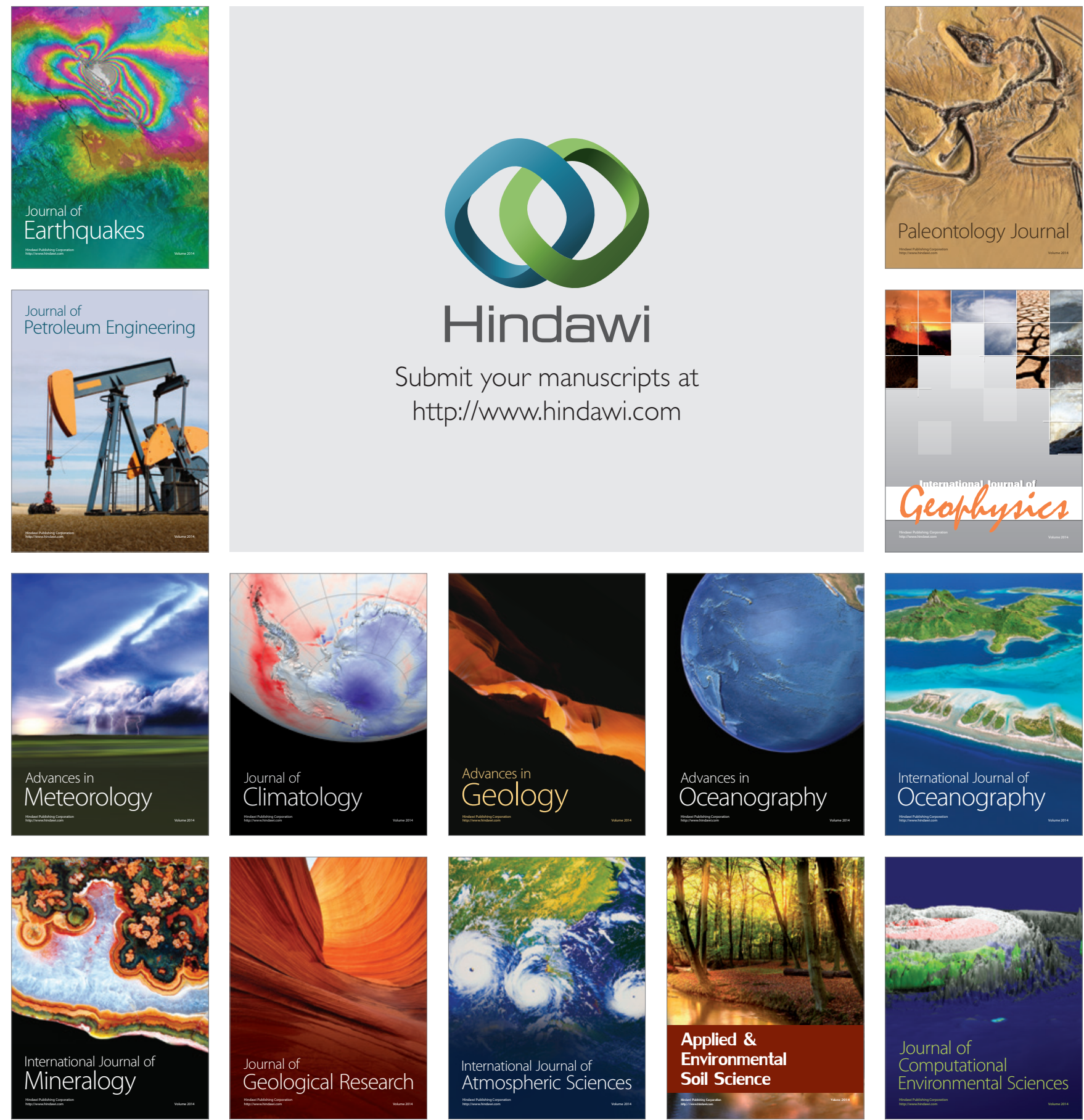